\title{
Biochemical and thermal properties of $\beta$-galactosidase enzymes produced by artisanal yoghurt cultures
}

\author{
Fatma Isık Ustok, Canan Tari *, Sebnem Harsa \\ Department of Food Engineering, Izmir Institute of Technology, Turkey
}

\section{A R T I C L E I N F O}

\section{Article history:}

Received 24 March 2009

Received in revised form 20 July 2009

Accepted 12 August 2009

\section{Keywords:}

$\beta$-Galactosidase

Streptococcus thermophilus

Lactobacillus delbrueckii ssp bulgaricus

Biochemical and thermal properties

\begin{abstract}
A B S T R A C T
$\beta$-Galactosidases, produced by pure and mixed cultures of Streptococcus thermophilus 95/2 (St 95/2) and Lactobacillus delbrueckii ssp bulgaricus 77 (Lb 77) isolated from the Toros mountain region of Turkey, were characterised with respect to their biochemical and thermal properties. Optimum $\mathrm{pH}$ and temperature for maximum activity were determined and these enzymes were stable in the $\mathrm{pH}$ range 7-9 and in the temperature range $20-37^{\circ} \mathrm{C}$, retaining $80-90 \%$ of their initial activities. The inactivation energies of $\beta$ galactosidase from Lb 77, St 95/2 and mixed culture (Lb 77 and St 95/2) were 51.3, 44.0 and $48.3 \mathrm{kcal} \mathrm{mol}^{-1}$, respectively. Moreover, thermodynamic $(\Delta G, \Delta S, \Delta H)$ and kinetic constants $\left(K_{m}\right.$ and $V_{\max }$ ) were determined and effects of metal ions were investigated. As a result, these enzymes could be considered as potential candidates for lactose hydrolysis of milk and milk products.
\end{abstract}

(c) 2009 Elsevier Ltd. All rights reserved.

\section{Introduction}

Galacto-oligosaccharides, which are considered as prebiotic food ingredients, are known as non-digestible carbohydrates. These substances are resistant to digestive enzymes. However, they are fermented by bifidobacteria and activate bifidobacteria in the intestinal micro biota (Ishikawa, Sakai, Ikemura, Matsumoto, \& Abe, 2005). Many $\beta$-galactosidases that produce galacto-oligosaccharides have been isolated from several microbial sources. Thus, discovering new strains producing high levels of this enzyme has gained importance.

$\beta$-Galactosidase (EC 3.2.1.23) is an enzyme that catalyse the hydrolysis of lactose (abundant disaccharide found in milk) to glucose and galactose; it has potential importance due to various applications of lactose-reduced ingredients in the food and dairy industry (Montanari, Zambonelli, Grazia, Benevelli, \& Chiavari, 2000; Voget, Flores, Faloci, \& Ertola, 1994). Major applications of $\beta$-galactosidase include improving the technological and sensorial characteristics of foods by increasing solubility, formation of galacto-oligosaccharides, assimilation of foods containing lactose for lactose intolerant populations and conversion of cheese whey into different value-added products (Cortes, Trujillo-Roldan, Ramirez, \& Galindo, 2005; Jurado, Camacho, Luzon, \& Vicaria, 2002; Vasiljevic \& Jelen, 2001).

\footnotetext{
* Corresponding author. Address: Izmir Institute of Technology, Department of Food Engineering, Gulbahce Campus, 35430 Urla-İzmir, Turkey. Tel.: +90 232 7506316; fax: +90 2327506196.

E-mail address: canantari@iyte.edu.tr (C. Tari).
}

The enzyme $\beta$-galactosidase has been found in various biological systems, such as plants and microorganisms. Yeasts, moulds and bacteria still remain the only sources for commercial purposes (Jurado et al., 2002; Vasiljevic \& Jelen, 2001). Enzymes from these microorganisms have different properties. Therefore, they can be used in different applications. $\beta$-Galactosidases obtained from mould have $\mathrm{pH}$ optima in the range 3-5 with an optimum temperature range of $55-60{ }^{\circ} \mathrm{C}$ with the limitations to high acid product applications and pharmaceutical preparations (Nagy, Kiss, Szentirmai, \& Biro, 2001). However, yeast $\beta$-galactosidases, recognised for their higher activities, are characterised by their neutral $\mathrm{pH}$ optima (Cortes et al., 2005; Jurado et al., 2002). In fact, the major drawback of these enzymes is their low optimum temperatures $\left(30-37^{\circ} \mathrm{C}\right)$ and low heat stabilities; inactivation is observed at temperatures above $48^{\circ} \mathrm{C}$ (Mahoney \& Wilder, 1989; Voget et al., 1994).

Therefore, in recent years, thermophilic lactic acid bacteria (LAB) have attracted great interest because of their GRAS status (generally regarded as safe). Among lactic acid bacteria, yogurt bacteria (Lactobacillus bulgaricus and Streptococcus thermophilus) are the highest $\beta$-galactosidase producers (Kreft \& Jelen, 2000; Shah \& Jelen, 1991). The $\beta$-galactosidase of these cultures has been characterised, showing high stability and activity at high temperatures (Greenberg \& Mahoney, 1982; Kreft \& Jelen, 2000; Kreft, Roth, \& Jelen, 2001). Such conditions, besides enhancing the rate of lactose hydrolysis, prevent the growth of undesirable microorganisms as well (Greenberg \& Mahoney, 1982).

136 LAB cultures, isolated from the Toros mountain region of Turkey, were screened and, among these strains, S. thermophilus 95/2 (St 95/2) and Lactobacillus delbrueckii ssp. bulgaricus 77 (Lb 
77) strains, were determined to be potential $\beta$-galactosidase enzyme producers (Tari, Ustok \& Harsa, 2009). These enzymes were characterised in view of the fact that enzymes from new sources may exhibit different properties and possible novelties. In this study, thermal and biochemical properties, and SDS-PAGE profiling were investigated. Another objective of the study was to compare the enzymes produced from pure cultures as opposed to mixed cultures. In fact, in our previous study (Tari, Ustok \& Harsa, 2009), we determined that the associative growth of the two strains in the same fermentation medium increased the enzyme yield significantly. Therefore, it is highly important to compare the properties of this enzyme (produced under associative growth conditions) with those produced by pure strains. That these enzymes are from newly isolated strains underlines the importance of this study. The results of this study may lead to freedom and flexibility of choice in using enzymes from pure or mixed strains. Using the enzymes from mixed strains would reduce the cost of buying the individual strains as the enzyme sources. Furthermore, the crude enzymes of LAB cultures are preferred since they already originate from cultures of GRAS status.

\section{Materials and methods}

\subsection{Culture propagation and fermentation}

Lactobacillus delbrueckii ssp bulgaricus 77 (Lb 77), and S. thermophilus 95/2 (St 95/2) used in this study were isolated from traditional yoghurt samples of the Toros mountain region of Turkey. These cultures were characterised on the basis of phenotypic and genotypic methods by the Molecular Food Biotechnology research group at Izmir Institute of Technology (Erkuş, Celik, Yavuzdurmaz, Okuklu, \& Harsa, 2006). Culture propagation was done in sterile M17 broth for St 95/2 and MRS broth for Lb 77 by transferring $10 \mu \mathrm{l}$ of stock culture (20\%) and incubating at $43^{\circ} \mathrm{C}$ for $16 \mathrm{~h}$.

Fermentation was carried out in $250 \mathrm{ml}$ Erlenmeyer flasks containing $100 \mathrm{ml}$ of sterilized broths $\left(113^{\circ} \mathrm{C} / 10 \mathrm{~min}\right.$.) of skim milk (8\%) for Lb 77 and whey $(5 \%, w / v)+$ corn steep liquor $(4 \%, w /$ $\mathrm{v})+$ peptone $(2 \%, \mathrm{w} / \mathrm{v})+$ potassium phosphate $(2 \%, \mathrm{w} / \mathrm{v})$ for St $95 /$ 2 and mixed cultures of $\mathrm{Lb} 77$ and St 95/2. These media were inoculated with $4 \%$ and $3.9 \%$ of Lb 77 and St $95 / 2$ for pure culture fermentation and $3 \%$ and $2.6 \%$ of $\mathrm{Lb} 77$ and St $95 / 2$ for mixed culture fermentation, respectively, and incubated at $43^{\circ} \mathrm{C}$ for $8 \mathrm{~h}$ without agitation. These inoculation amounts were based on our initial optimisation study (Tari, Ustok, \& Harsa, 2009).

\subsection{Extraction of enzyme and $\beta$-galactosidase activity assay}

Since $\beta$-galactosidase from $S$. thermophilus and Lactobacillus delbrueckii ssp. bulgaricus is an intracellular enzyme, lysozyme treatment was used for enzyme extraction. Therefore, $10 \mathrm{ml}$ of the harvested fermentation broth was centrifuged at $2800 \mathrm{~g}$ for $15 \mathrm{~min}$ at $4{ }^{\circ} \mathrm{C}$ after which the pellet was washed with $10 \mathrm{ml}$ of $0.05 \mathrm{M} \mathrm{Na}$-phosphate buffer ( $\mathrm{pH} 7$ ). After centrifugation at $2800 \mathrm{~g}$ for a further $15 \mathrm{~min}$, the pellet was resuspended in $4.5 \mathrm{ml}$ of the same buffer, followed by vigorous vortexing. For enzymatic lysis, $100 \mathrm{mg}$ lysozyme (Sigma L 6876) were added to this solution and it was incubated at $37^{\circ} \mathrm{C}$ for $15 \mathrm{~min}$. Following this period, $0.5 \mathrm{ml}$ of $4 \mathrm{M} \mathrm{NaCl}$ solution was added and it was incubated at $37^{\circ} \mathrm{C}$ for a further $50 \mathrm{~min}$. Finally, the solutions were centrifuged at $2800 \mathrm{~g}$ for $15 \mathrm{~min}$ and the supernatant was used for the enzyme and protein assay.

The procedure used to determine $\beta$-galactosidase activity was described in the Food Chemicals Codex-National Academy of Sciences where o-nitrophenol-beta-D-galactopyranoside (ONPG) $\left(8.3 \times 10^{-3} \mathrm{M}\right)$ dissolved in $0.05 \mathrm{M}$ sodium phosphate buffer $(\mathrm{pH}$
7.0) was used as substrate (Food Chemical Codex, 1996). The amounts of substrate and enzyme used in the assay were 2 and $0.5 \mathrm{ml}$, respectively. At time zero, $0.5 \mathrm{ml}$ of enzyme solution was added to the ONPG solution and incubated for $15 \mathrm{~min}$. The assay was stopped by the addition of $0.5 \mathrm{ml}$ of $10 \%$ sodium carbonate, and the absorbance was determined at $420 \mathrm{~nm}$. One unit was defined as the quantity of enzyme that would liberate $1 \mathrm{mmol}$ of onitrophenol from ONPG per minute under the assay conditions.

\subsection{Protein assay}

Protein concentration was determined by Bradford dye-binding assay, using BSA as a standard (Roe, 2001).

\subsection{Electrophoresis}

The molecular weight of the subunits was estimated by SDSPAGE, using a vertical gel electrophoresis system. SDS-PAGE was performed according to the procedure described by Laemmli (1970), using 10\% resolving gel and 4\% stacking gel. The proteins were stained by Coomassie brilliant blue and destained using methanol-water containing $10 \%$ acetic acid.

\subsection{Effect of $\mathrm{pH}$ on activity and stability of $\beta$-galactosidase}

The effect of $\mathrm{pH}$ on the activity of $\beta$-galactosidase was determined by assaying the enzyme activity at different $\mathrm{pH}$ values ranging from 4.5 to 9.0 , using $0.05 \mathrm{M}$ concentrations of the following buffer systems: sodium acetate ( $\mathrm{pH} 4.5,5.0$ and 5.5), sodium phosphate ( $\mathrm{pH} \mathrm{6.0,6.5,} \mathrm{7.0} \mathrm{and} \mathrm{7.5)} \mathrm{and} \mathrm{Tris-} \mathrm{HCl}(\mathrm{pH} \mathrm{8.0,} 8.5$ and 9.0). The relative activities were expressed as percentages. The $\mathrm{pH}$ stability of $\beta$-galactosidase was investigated using the buffer systems described above. Enzyme solutions were mixed with the buffer solutions and incubated at $37^{\circ} \mathrm{C}$ for $30 \mathrm{~min}$. Afterwards aliquots of the mixtures were taken to measure the residual $\beta$-galactosidase activity (\%) with respect to control, under standard assay conditions.

\subsection{Effects of temperature on activity and stability of $\beta$-galactosidase}

The effect of temperature on the activity of $\beta$-galactosidase was determined by performing the standard enzyme assay procedure at different temperatures ranging from $20^{\circ} \mathrm{C}$ to $65^{\circ} \mathrm{C}$. Substrate (ONPG) was preincubated at the respective temperatures for $5 \mathrm{~min}$. The relative activities (as percentages) were expressed as the ratio of the $\beta$-galactosidase activity obtained at a certain temperature to the maximum activity obtained in the given temperature range. In order to determine the thermostability of the crude enzyme, residual activities were measured after incubating the enzyme at various temperatures ranging from $20^{\circ} \mathrm{C}$ to $65^{\circ} \mathrm{C}$ for $30 \mathrm{~min}$.

\subsection{Kinetics of thermal inactivation and estimation of the inactivation energy}

In order to investigate the thermal inactivation kinetics of $\beta$ galactosidase, crude enzyme extracts were incubated at different temperatures $\left(45^{\circ} \mathrm{C}, 50^{\circ} \mathrm{C}, 55^{\circ} \mathrm{C}\right.$, and $\left.60{ }^{\circ} \mathrm{C}\right)$ in the absence of the substrate. Aliquots were withdrawn at periodic intervals and cooled in an ice bath prior to assay. The residual activity was expressed as\% of the initial activity. From a semi-natural logarithmic plot of residual activity versus time, the inactivation rate constants $\left(k_{d}\right)$ were calculated and apparent half-lives were estimated using the Eq. (1). The half-life $\left(t_{1 / 2}\right)$ is defined as the time where the residual activity reaches $50 \%$.

$t_{1 / 2}=\frac{\ln 2}{k_{d}}$ 
The temperature dependence of $k_{d}$ was analysed using the Arrhenius plot (Shuler \& Kargi, 2002). The inactivation energy was calculated from the Arrhenius equation as:

$\ln K_{d}=\ln \left(k_{0}\right)-\left(\frac{E}{R}\right) \frac{1}{T}$

The values of $E$ and $k_{0}$ were estimated from the slope and intercept of the plot of $\ln \left(k_{d}\right)$ versus $1 / T$, respectively.

\subsection{Estimation of thermodynamic parameters}

In order to determine the thermodynamic values, the enthalpy of inactivation $\left(\Delta H^{*}\right)$ and Gibb's free energy of inactivation were calculated for given temperature values according to following equations (Eqs. (3) and (4)).

$\Delta H^{*}=E_{d}-R T$

$\Delta G^{*}=-R T \ln \left(\frac{k_{d} h}{k T}\right)$

where $R$ is the universal gas constant, $T$ is the absolute temperature, $h\left(=6.6262 \times 10^{-34} \mathrm{Js}\right)$ is the Plank constant, and $K(=1.3806 \times$ $\left.10^{-23}\right)$ is the Boltzmann constant.

In addition, the entropy of inactivation $\left(\Delta S^{*}\right)$ of $\beta$-galactosidase was calculated from Eq. (5)

$\Delta S^{*}=\frac{\left(\Delta H^{*}-\Delta G^{*}\right)}{T}$

\subsection{Determination of kinetic constants}

The kinetic constants $\left(V_{\max }\right.$ and $\left.K_{m}\right)$ were determined using Lineweaver-Burk double reciprocal $(1 / V$ versus $1 / S)$ plots where different substrate concentrations $(0.33-2 \mathrm{mM})$ at $\mathrm{pH} 7.0$ and $37^{\circ} \mathrm{C}$ were used (Shuler \& Kargi, 2002).

$\frac{1}{v}=\frac{1}{V_{m}}+\frac{K_{m}}{V_{m}} \frac{1}{[S]}$

\subsection{Effect of metal ions on activity}

The effect of metal ions $\left(\mathrm{K}^{+}, \mathrm{Na}^{+}, \mathrm{Ca}^{+2}, \mathrm{Mg}^{+2}, \mathrm{Mn}^{+2}, \mathrm{Zn}^{+2}, \mathrm{Cu}^{+2}\right.$ and $\mathrm{Fe}^{+2}$ ) were evaluated on $\beta$-galactosidase activity, using sodium phosphate buffer, $\mathrm{pH}$ 7.0. The enzyme was preincubated for $30 \mathrm{~min}$ at $37{ }^{\circ} \mathrm{C}$ with various final concentrations $(1-10 \mathrm{mM})$ of metal ions prior to the substrate addition. Activity without added metal ions was taken as $100 \%$ activity.

\subsection{Hydrolysis of lactose}

In order to test the level of lactose hydrolysis, 5\% lactose solution was prepared by dissolving lactose in $0.05 \mathrm{M}$ sodium phosphate buffer, $\mathrm{pH}$ 7.0. Crude enzyme extracts of pure and mixed cultures, in amounts of $1 \mathrm{ml}$, were added to each tube containing $1 \mathrm{ml}$ of lactose solution (1:1 ratio). These tubes were incubated at $37^{\circ} \mathrm{C}$ for $8 \mathrm{~h}$ and aliquots were removed at regular intervals to test lactose content. The amount of lactose hydrolysis was determined by using the HPLC method described by Büyükkileci and Harsa (2004). The result was expressed as percent lactose hydrolysed.

\section{Results and discussion}

\subsection{Effect of $\mathrm{pH}$ on activity and stability of $\beta$-galactosidase}

The effect of $\mathrm{pH}$ on the activity of $\beta$-galactosidase for the crude enzyme extracts obtained from Lb 77, St 95/2 and Lb 77 and St 95/2 (mixed culture) was investigated and is presented in Fig. 1a. The optimum $\mathrm{pH}$ was determined as $\mathrm{pH} 7$ for enzymes obtained from three sources. These findings were in accordance with several earlier literature studies. In a study performed by Greenberg and Mahoney (1982) optimum $\mathrm{pH}$ for $\beta$-galactosidase from $S$. thermophilus was found to be 7.0. Similar findings were observed in another study performed by Kreft and Jelen (2000).

The $\mathrm{pH}$ stability profile at $37^{\circ} \mathrm{C}$ is shown in Fig. 1b. The enzymes were essentially stable (85-90\%) over the $\mathrm{pH}$ range 7-9. Enzymes from Lactobacillus delbrueckii ssp bulgaricus and $S$. thermophilus appear to be stable over a wider $\mathrm{pH}$ range than Escherichia coli $\beta$-galactosidase whose stability decreases sharply below pH 6 and more gradually above 8 (Greenberg \& Mahoney, 1982).

In order to estimate whether there were differences in the $\mathrm{pH}$ profiles of enzymes obtained from pure cultures and mixed cultures, a two sample $t$-test was performed by using Minitab 14 (Minitab Inc., PA, USA) (data not shown). Since the $p$-values $(p>0.05)$ obtained by the programme were greater than commonly chosen $\alpha$-levels, these results indicated that there was no evidence for a difference in the $\mathrm{pH}$ profiles when using pure culture versus mixed culture. As can be deduced from the results, enzymes from these sources have similar $\mathrm{pH}$ profiles and seem well-suited for hydrolysis of lactose in milk, since they exhibited good activity and stability at $\mathrm{pH}$ values close to neutral.

\subsection{Effect of temperature on activity and stability of $\beta$-galactosidase}

$\beta$-Galactosidases from Lb 77, St 95/2 and mixed culture (Lb 77 and St 95/2) were found to have optimum temperatures of $45^{\circ} \mathrm{C}$, $50{ }^{\circ} \mathrm{C}$ and $50^{\circ} \mathrm{C}$, respectively. These enzymes retained $90-100 \%$ of their activity between $45^{\circ} \mathrm{C}$ and $55^{\circ} \mathrm{C}$ (Fig. 1a). Similar findings were reported in several literature studies. For example, Shah and Jelen (1991) found the optimum temperature of $\beta$-galactosidase from Lactobacillus delbrueckii ssp. bulgaricus 11842 to be $45-$ $50{ }^{\circ} \mathrm{C}$. Similarly, maximum activity for $\beta$-galactosidase from $S$. thermophilus was $55^{\circ} \mathrm{C}$ (Greenberg \& Mahoney, 1982).

Thermostability is described as the ability of an enzyme to resist thermal unfolding in the absence of substrates (Bhatti, Asgher, Abbas, Nawaz, \& Sheikh, 2006). The thermostability of the crude $\beta$ galactosidases from all three sources was determined by measuring the residual activity of the enzyme after incubation at various temperatures ranging from $20^{\circ} \mathrm{C}$ to $65^{\circ} \mathrm{C}$ for $30 \mathrm{~min}$. As shown in Fig. 1 b, the $\beta$-galactosidases from Lb 77, St 95/2 and Lb 77 and St $95 / 2$ were stable at temperatures between $20^{\circ} \mathrm{C}$ and $37^{\circ} \mathrm{C}$. However, at $40{ }^{\circ} \mathrm{C} \beta$-galactosidase activity increased 6\%, 9\% and 10\% above the control, respectively. The activation of enzymes during heating occurs mostly during the initial stages of mild heating and is generally attributed to conformational changes in the enzyme active site (Rodriguez-Lopez et al., 1999). However, after the incubation of the enzymes at $55{ }^{\circ} \mathrm{C}, \beta$-galactosidase activity was reduced to $54.5 \%, 57.3 \%$ and $53.7 \%$ for $\mathrm{Lb} 77$, St $95 / 2$ and $\mathrm{Lb}$ 77 and St 95/2, respectively, and almost all crude extracts lost $95 \%$ of activity at $65^{\circ} \mathrm{C}$. A two sample $t$-test was also performed to investigate the differences in the temperature profiles of pure and mixed cultures by using statistical software Minitab 14 (Minitab Inc., PA, USA) (data not shown). Results of these analyses showed that there was no significant difference $(p>0.05)$ in the temperature profiles of the enzymes obtained from pure and mixed strains, which proved that enzymes had similar characteristics.

\subsection{Kinetics of thermal inactivation and estimation of the inactivation energy}

Inactivation is known to be a process where the secondary, tertiary or quaternary structure of a protein changes without breaking 
a)

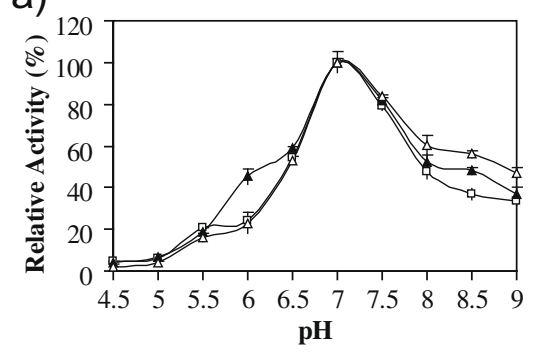

b)

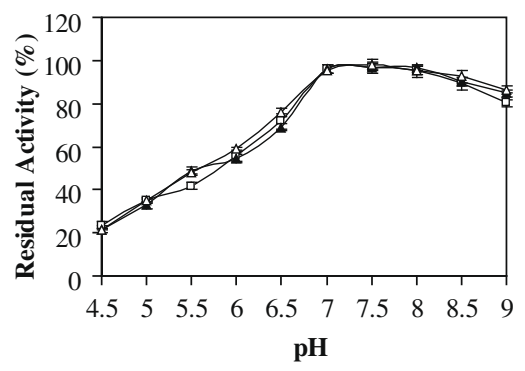

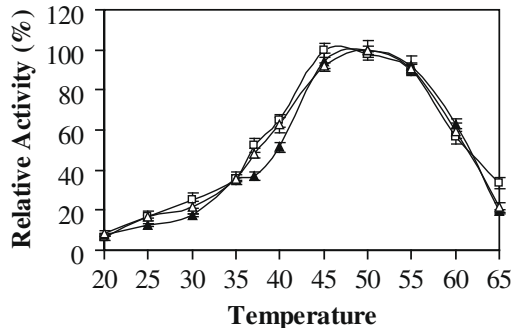

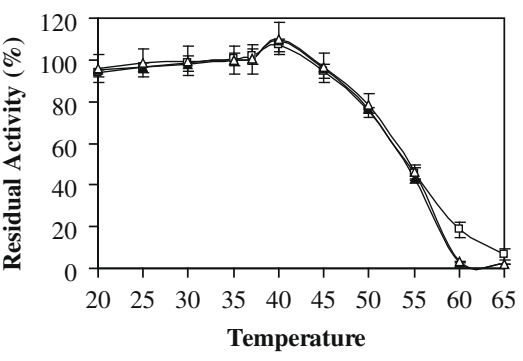

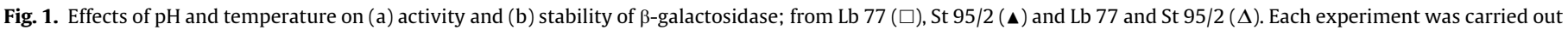
three times. (Temperature is shown in ${ }^{\circ} \mathrm{C}$.)

covalent bonds (Naidu \& Panda, 2003). Inactivation rate constants $\left(k_{d}\right)$ of $\beta$-galactosidases obtained from Lb 77, St 95/2 and mixed culture of Lb 77 and St 95/2, which are presented in Table 1 at $45^{\circ} \mathrm{C}, 50^{\circ} \mathrm{C}, 55^{\circ} \mathrm{C}$ and $60^{\circ} \mathrm{C}$, were calculated from the slope of semi-natural logarithmic plot of residual activity versus time. Similarly the half-life values were calculated using inactivation rate constants. These values are also presented in Table 1 .

The half-lives of $\beta$-galactosidases for all three sources at $45^{\circ} \mathrm{C}$ were higher than those at temperatures of $50{ }^{\circ} \mathrm{C}, 55^{\circ} \mathrm{C}$ and $60^{\circ} \mathrm{C}$ at $\mathrm{pH}$ 7. This issue once again reveals the thermal stability of this enzyme at $45^{\circ} \mathrm{C}$ and its inactivation at higher temperatures $\left(60{ }^{\circ} \mathrm{C}\right)$. Comparison of half-lives of the enzymes at $45^{\circ} \mathrm{C}$ revealed that the enzyme obtained from Lb 77 was more stable than the enzymes obtained from the other sources (St 95/2 and mixed culture). This significant difference was also tested and confirmed by a two sample $t$-test $(p<0.01)$.

Inactivation energies $\left(E_{d}\right)$ of crude $\beta$-galactosidase from Lb 77, St 95/2 and mixed culture of Lb 77 and St 95/2 were found to be 51.3, 44.0 and $48.3 \mathrm{kcal} \mathrm{mol}^{-1}$, respectively. These values are in the range (40-70 $\mathrm{kcal} \mathrm{mol}^{-1}$ ) estimated for many microbial enzymes (Shuler \& Kargi, 2002).

\subsection{Estimation of thermodynamic parameters}

To determine industrial potentials of $\beta$-galactosidases, it is essential to discover new microbial strains and to understand the structure-stability relationships of the enzymes they produce. Therefore, estimation of thermodynamic parameters helps to understand the probable mechanism of denaturation which is very important in enzymatic processes. The changes in enthalpy $\left(\Delta H^{*}\right)$ and entropy $\left(\Delta S^{*}\right)$, for the thermal inactivation of $\beta$-galactosidase, which have been calculated using transition state theory are presented in Table 2 . As the $\Delta H^{*}$ and $\Delta S^{*}$ are heat and entropy change, respectively, these two parameters also provide a measure of the number of non-covalent bonds broken and the net enzyme/solvent disorder change associated with the formation of the transition state (Ortega, de Diego, Perez-Mateos, \& Busto, 2004). As is seen from Table 2, with an increase of temperature, a slight decrease in $\Delta H^{*}$ and an increase in $\Delta S^{*}$ were observed. This also suggests thermal denaturation of the enzymes, which could be because of disruption of non-covalent linkages, including hydrophobic interactions.

It is reported that formation of unfolded enzyme can be confirmed by an increase in the entropy or disorder of inactivation. The increase in $\Delta S^{*}$ also indicates an increase in number of protein molecules in the transition activated stage, which in turn results in lower values of $\Delta G^{*}$. A large positive $\Delta S^{*}$ would suggest that the inactivation is highly accompanied by an unfolding of the polypeptide chain into a less highly ordered, more random structure. $\Delta S^{*}$ values are important as they provide information regarding the degree of solvation and the degree of compactness of a protein molecule. Furthermore, positive entropy values suggest that enzyme

Table 1

Kinetic parameters for thermal inactivation of $\beta$-galactosidase: from Lb 77, St 95/2 and mixed culture of Lb 77 and St 95/2.

\begin{tabular}{|c|c|c|c|c|c|c|}
\hline \multirow[t]{2}{*}{$T\left({ }^{\circ} \mathrm{C}\right)$} & \multicolumn{3}{|l|}{$K_{d}^{\mathrm{a}}$} & \multicolumn{3}{|c|}{$\underline{t_{1 / 2}(\min )}$} \\
\hline & Lb 77 & St $95 / 2$ & Lb 77 and St $95 / 2$ & Lb 77 & St $95 / 2$ & Lb 77 and St $95 / 2$ \\
\hline 45 & 0.0021 & 0.0033 & 0.0025 & 330.07 & 210.04 & 277.25 \\
\hline 50 & 0.0092 & 0.0104 & 0.0089 & 75.34 & 66.65 & 77.88 \\
\hline 55 & 0.0270 & 0.0187 & 0.0194 & 25.67 & 37 & 35.73 \\
\hline 60 & 0.0970 & 0.0990 & 0.0995 & 7.14 & 7 & 6.96 \\
\hline
\end{tabular}

a From slope of the semilogarithmic plot of residual activity versus time for each temperature, the inactivation rate constants ( $\left.K_{d}\right)$ were calculated for all samples.

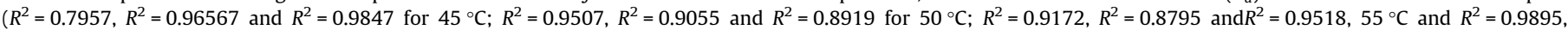
$R^{2}=0.9759$ and $R^{2}=0.9946$ for $60^{\circ} \mathrm{C}$ for Lb 77 , St $95 / 2$ and Lb 77 and St 95/2, respectively). 
Table 2

Thermodynamic parameter values of thermal inactivation of $\beta$-galactosidases from Lb 77, St 95/2 and Lb 77 and St 95/2 at different temperatures.

\begin{tabular}{|c|c|c|c|c|c|c|c|c|c|}
\hline \multirow[t]{2}{*}{$T(\mathrm{~K})$} & \multicolumn{3}{|c|}{$\Delta H^{*}\left(\mathrm{~kJ} \mathrm{~mol}^{-1}\right)$} & \multicolumn{3}{|c|}{$\Delta G^{*}\left(\mathrm{~kJ} \mathrm{~mol}^{-1}\right)$} & \multicolumn{3}{|c|}{$\Delta S^{*}\left(\mathrm{~kJ} \mathrm{~mol}^{-1} \mathrm{~K}^{-1}\right)$} \\
\hline & Lb 77 & St $95 / 2$ & Lb 77 and St $95 / 2$ & Lb 77 & St $95 / 2$ & Lb 77 and St $95 / 2$ & Lb 77 & St $95 / 2$ & Lb 77 and St $95 / 2$ \\
\hline 318 & 213.80 & 183 & 201 & 105 & 104 & 105 & 0.339 & 0.248 & 0.302 \\
\hline 323 & 213.76 & 183 & 201 & 103 & 103 & 103 & 0.343 & 0.249 & 0.303 \\
\hline 328 & 213.72 & 183 & 201 & 102 & 103 & 103 & 0.341 & 0.245 & 0.299 \\
\hline 333 & 213.68 & 183 & 201 & 99.7 & 99.6 & 99.6 & 0.342 & 0.250 & 0.304 \\
\hline
\end{tabular}

unfolding might be the rate determining step for the irreversible thermo-inactivation of the enzyme. Numerical values of $\Delta H^{*}$ and $\Delta S^{*}$ are highly influenced by various factors, including the solvent and structural effects (Naidu \& Panda, 2003).

As is seen from Table $2, \Delta S^{*}$ values are close to zero, showing that thermal inactivation did not imply any relevant variation in the enzyme tertiary structure. In other words, most of the hydrogen bonds responsible for the active structure of catalytic site of the enzyme were still present in the activated complex. The effect of temperature on the rate of the denaturation can be explained by the usual thermodynamic values. The rate of denaturation of these enzymes was slow at low temperature, but it increased rapidly with increase in the temperature. Along with the increase in the temperature of denaturation from $45^{\circ} \mathrm{C}$ to $55^{\circ} \mathrm{C}$, the half-lives of these enzymes decreased from 330, 210, 277 to 25.7, 37, and 35.7 for Lb 77, St 95/2 and Lb 77 and St 95/2, respectively (Table 1 ). These enzymes were found to be more stable at $45^{\circ} \mathrm{C}$ than at the other temperatures studied.

\subsection{Calculation of kinetic constants}

The kinetic parameters of $\beta$-galactosidase from Lb 77 , St $95 / 2$ and mixed culture (Lb 77 and St 95/2) for hydrolysis of o-nitrophenyl- $\beta$-D-galactopyranoside (ONPG) at $\mathrm{pH} 7{ }^{\circ} \mathrm{C}$ and $37^{\circ} \mathrm{C}$ were obtained by a typical double reciprocal Lineweaver Burk plot (Shuler \& Kargi, 2002). The apparent $K_{m}$ and $V_{m}$ values for hydrolysing ONPG were calculated. $K_{m}$ and $V_{m}$ values were $1.72,0.981$ and $3.67 \mathrm{mM}$ and 2.46, 2.99 and $3.44 \mu \mathrm{mol} / \mathrm{min}$ for Lb 77, St 95/2 and mixed culture (Lb 77 and St 95/2), respectively. The estimated $K_{m}$ value of the enzyme from mixed culture (Lb 77 and St 95/2) was 2.13 and 3.74 times higher (lower affinity) than the Lactobacillus delbrueckii ssp bulgaricus 77 and S. thermophilus 95/2) $\beta$-galactosidases, respectively. This indicates that $\beta$-galactosidase from $S$. thermophilus 95/2 has a higher affinity for ONPG than have the other two. The values of $K_{m}$ for these enzymes are of the same order of magnitude as $\beta$-galactosidases from other microbial sources. Greenberg and Mahoney (1982), found a similar $K_{m}$ value ( $0.98 \mathrm{mM}$ ) by using $S$. thermophilus strains. In the same study the $K_{m}$ value of $\beta$-galactosidase from Lactobacillus thermophilus was found to be $1.7 \mathrm{mM}$ (Greenberg \& Mahoney, 1982).

\subsection{SDS-PAGE profiles}

SDS-PAGE profiling (Fig. 2) revealed that the crude enzyme from Lb 77, St 95/2 and mixed culture of Lb 77 and St 95/2 were composed of eight, seven and seven main fractions, respectively. Since the crude enzymes were not purified, it is difficult to know whether these bands were different $\beta$-galactosidases or other enzymes. This issue remains a task to perform in future studies. It is also not possible to compare these bands with commercial $\beta$ galactosidase since commercial enzymes from lactic acid bacteria are not available.

However, evaluation of these crude extracts by SDS-PAGE is important. As is seen from the Fig. 2, crude extract from mixed culture showed the same pattern as the crude extract from St 95/2,

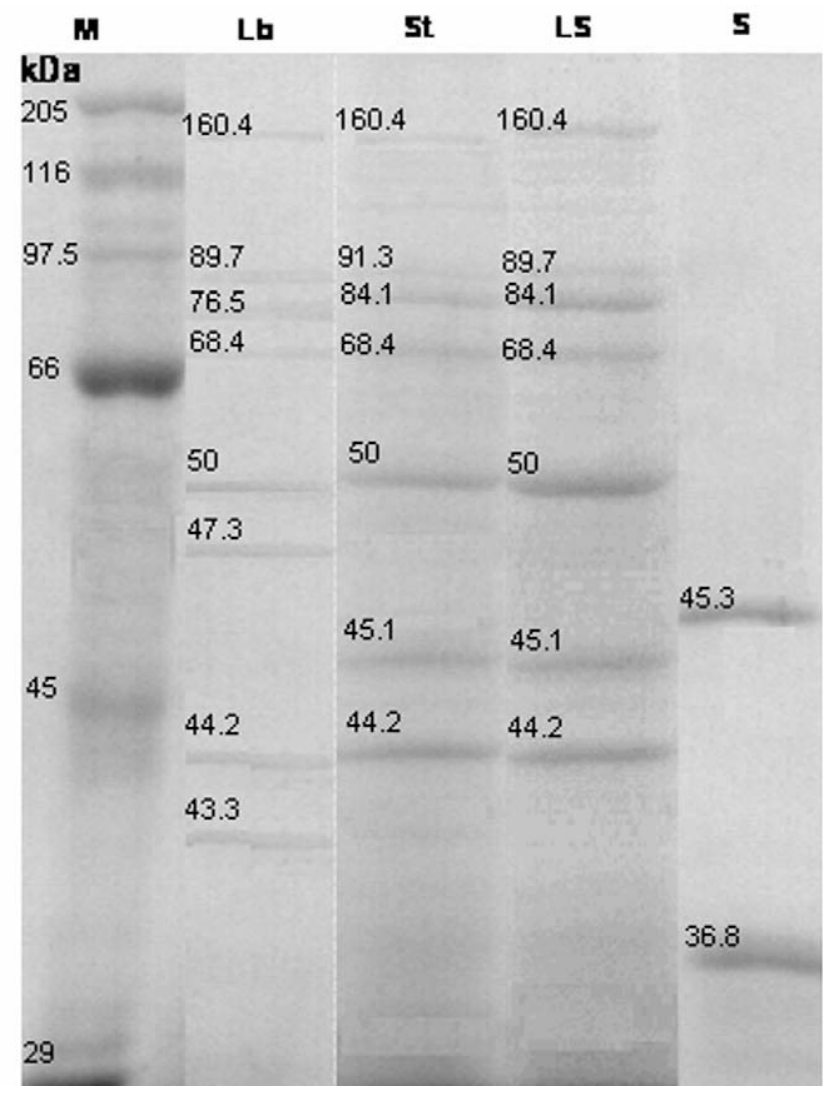

Fig. 2. SDS-PAGE profiles of crude $\beta$-galactosidase extracts: Lane $M$, marker proteins; lane Lb, $\beta$-galactosidase from Lb 77; lane St, $\beta$-galactosidase from St 95/2, lane LS, $\beta$-galactosidase from Lb 77 and St 95/2, and lane S, commercial $\beta$ galactosidase from Saccharomyces fragilis.

whereas two different bands, with molecular weights of 47.3 and $43.3 \mathrm{kDa}$, were obtained in the crude extract from $\mathrm{Lb} 77$.

In literature, wide variations in molecular weights of $\beta$-galactosidases from microbial sources have been reported. Many $\beta$-galactosidases, containing numerous subunits with various molecular weights, have been described (Berger, Lee, \& Lacroix, 1997). Among $\beta$-galactosidases from thermophilic microorganisms, molecular weights of $150,240,440$ and $700 \mathrm{kDa}$ were reported by Berger et al. (1997).

\subsection{Effect of metal ions on $\beta$-galactosidase activity}

Various cations present in the solution may have different effects as activators or inhibitors during the hydrolysis process. Therefore the effects of metal ions were examined by adding the chlorides of $\mathrm{K}^{+}, \mathrm{Na}^{+}, \mathrm{Ca}^{2+}, \mathrm{Mg}^{2+}, \mathrm{Mn}^{2+}$ and $\mathrm{Zn}^{2+}$ and sulphates of $\mathrm{Cu}^{2+}$ and $\mathrm{Fe}^{2+}$, at different concentrations, to the buffer solutions. As can be observed from Table $3, \mathrm{Ca}^{2+}, \mathrm{Zn}^{2+}$ and $\mathrm{Cu}^{2+}$ had inhibitory effects on the $\beta$-galactosidase obtained from Lb 77, St 95/2 and 
Table 3

Effects of metal ions on the activity of crude $\beta$-galactosidase: from Lb 77, St 95/2 and Lb 77 and St 95/2.

\begin{tabular}{|c|c|c|c|c|}
\hline \multirow{3}{*}{$\begin{array}{l}\text { Strain Lb } 77 \\
\text { Control } \\
\text { Metal ions }\end{array}$} & \multicolumn{4}{|c|}{ \% Relative activity ${ }^{\mathrm{b}}$} \\
\hline & \multicolumn{4}{|l|}{100} \\
\hline & $1(\mathrm{mM})$ & $2.5(\mathrm{mM})$ & $5(\mathrm{mM})$ & $10(\mathrm{mM})$ \\
\hline $\mathrm{K}^{+}$ & $97.5 \pm 1.13$ & $94.3 \pm 1.61$ & $96.2 \pm 3.10$ & $98.4 \pm 1.53$ \\
\hline $\mathrm{Na}^{+}$ & $98.4 \pm 0.92$ & $99.6 \pm 2.18$ & $91.3 \pm 2.17$ & $88.0 \pm 1.78$ \\
\hline $\mathrm{Ca}^{2+}$ & $55.0 \pm 1.78$ & $35.0 \pm 0.76$ & $28.0 \pm 1.27$ & $15.0 \pm 1.05$ \\
\hline $\mathrm{Mg}^{2+}$ & $97.7 \pm 2.10$ & $104 \pm 4.09$ & $105 \pm 2.64$ & $108 \pm 1.75$ \\
\hline $\mathrm{Mn}^{2+}$ & $100.8 \pm 2.43$ & $106.25 \pm 2.38$ & $117.7 \pm 2.12$ & $122.8 \pm 1.98$ \\
\hline $\mathrm{Zn}^{2+}$ & $55.0 \pm 1.78$ & $40.0 \pm 1.40$ & $25.0 \pm 1.06$ & $0 \pm 0$ \\
\hline $\mathrm{Cu}^{2+}$ & $25.0 \pm 0.98$ & $18.0 \pm 0.94$ & $5.0 \pm 0.45$ & $0 \pm 0$ \\
\hline $\mathrm{Fe}^{2+}$ & $90.0 \pm 1.34$ & $85.0 \pm 1.85$ & $75.0 \pm 0.97$ & $30.0 \pm 1.73$ \\
\hline \multicolumn{5}{|l|}{ Strain St 95/2 } \\
\hline $\mathrm{K}^{+}$ & $93.9 \pm 1.45$ & $99.3 \pm 2.26$ & $97.7 \pm 1.54$ & $98.0 \pm 2.11$ \\
\hline $\mathrm{Na}^{+}$ & $98.8 \pm 2.10$ & $96.7 \pm 1.31$ & $92.7 \pm 2.18$ & $90.1 \pm 1.42$ \\
\hline $\mathrm{Ca}^{2+}$ & $48.1 \pm 0.78$ & $26.0 \pm 0.67$ & $12.0 \pm 0.94$ & $10.0 \pm 0.76$ \\
\hline $\mathrm{Mg}^{2+}$ & $98.7 \pm 1.96$ & $102 \pm 1.18$ & $104 \pm 3.06$ & $110 \pm 2.83$ \\
\hline $\mathrm{Mn}^{2+}$ & $102 \pm 2,76$ & $108 \pm 2.07$ & $109 \pm 2.86$ & $130 \pm 1.05$ \\
\hline $\mathrm{Zn}^{2+}$ & $58.0 \pm 1.09$ & $45.0 \pm 1.14$ & $15.0 \pm 1.03$ & $0 \pm 0$ \\
\hline $\mathrm{Cu}^{2+}$ & $6.63 \pm 0.02$ & $0 \pm 0$ & $0 \pm 0$ & $0 \pm 0$ \\
\hline $\mathrm{Fe}^{2+}$ & $93.0 \pm 1.51$ & $88.0 \pm 2.16$ & $77.0 \pm 2.21$ & $25.0 \pm 1.76$ \\
\hline \multicolumn{5}{|c|}{ Strains (Lb 77 and St 95/2) } \\
\hline $\mathrm{K}^{+}$ & $99.4 \pm 1.65$ & $97.1 \pm 1.54$ & $95.7 \pm 1.24$ & $98.1 \pm 2.28$ \\
\hline $\mathrm{Na}^{+}$ & $94.9 \pm 2.30$ & $93.8 \pm 2.75$ & $90.2 \pm 2.26$ & $89.3 \pm 2.53$ \\
\hline $\mathrm{Ca}^{2+}$ & $64.2 \pm 0.89$ & $46.0 \pm 1.27$ & $27.0 \pm 0.74$ & $14.0 \pm 0.65$ \\
\hline $\mathrm{Mg}^{2+}$ & $99.4 \pm 2.61$ & $103.3 \pm 3.21$ & $107 \pm 1.17$ & $111 \pm 2.09$ \\
\hline $\mathrm{Mn}^{2+}$ & $116 \pm 3.13$ & $134 \pm 1.25$ & $160 \pm 2.11$ & $167 \pm 1.76$ \\
\hline $\mathrm{Zn}^{2+}$ & $56.0 \pm 1.16$ & $40.0 \pm 1.28$ & $21.0 \pm 0.63$ & $0 \pm 0$ \\
\hline $\mathrm{Cu}^{2+}$ & $5.29 \pm 0.87$ & $0 \pm 0$ & $0 \pm 0$ & $0 \pm 0$ \\
\hline $\mathrm{Fe}^{2+}$ & $91.0 \pm 1.02$ & $83.0 \pm 2.14$ & $72.0 \pm 1.13$ & $28.0 \pm 2.17$ \\
\hline
\end{tabular}

b Each experiment was carried out three times and data are given as means \pm standard deviation.

mixed culture (Lb 77 and St 95/2). However, $\mathrm{Mg}^{2+}$ and $\mathrm{Mn}^{2+}$ caused activation in all enzymes. In fact, the effects of these ions depended on their concentrations. For example, increase in concentration of $\mathrm{Ca}^{2+}$ caused deactivation of the enzyme, whereas increase in the concentrations of $\mathrm{Mg}^{2+}$ and $\mathrm{Mn}^{2+}$ caused activation. Another important observation was that, at 1 and $2.5 \mathrm{mM}$ concentrations of $\mathrm{Ca}^{2+}$, the $\beta$-galactosidase activity of mixed cultures was enhanced compared to the pure ones. Similar effects were observed for $\mathrm{Mg}^{2+}$ and $\mathrm{Mn}^{2+}$ regardless of the concentration used. This observation revealed, that the $\beta$-galactosidase structure and its active site obtained from mixed culture might be different from those of pure cultures. This would favour the lactose hydrolysis in $\mathrm{Ca}^{2+}-, \mathrm{Mg}^{2+}$ - and $\mathrm{Mn}^{2+}$-rich dairy products. Similarly, increasing the concentration of $\mathrm{Fe}^{2+}$ from 1.0 to $10 \mathrm{mM}$ resulted in 3-, 3.72and 3.25-fold reductions in the $\beta$-galactosidase activities of the enzymes obtained from Lb 77, St 95/2 and mixed culture (Lb 77 and St 95/2), respectively.

In various studies reported in the literature, different results were obtained, depending on the ion, the substrate used and the source of $\beta$-galactosidase. The effect of monovalent cations $\left(\mathrm{K}^{+}\right.$ and $\mathrm{Na}^{+}$) varies with the enzymes from different sources (Jurado et al., 2002). For the enzyme from $S$. thermophilus and ONPG as a substrate, no effect was found in one case (Somkuti \& Steinberg, 1979); however, slight activation was observed in another (Rao \& Dutta, 1981). Greenberg and Mahoney (1982) found highest activity with $\mathrm{K}^{+}$in the presence of $\mathrm{Mn}^{2+}$. Similarly, presence or absence of $\mathrm{Mg}^{2+}$ showed different effects. In a study performed by Bhowmik, Johnson, and Ray (1987), $\beta$-galactosidase from Lactobacillus acidophilus was stimulated with $\mathrm{Mg}^{2+}$ whereas, in another study, it had no effect in the case of Lactobacillus kefiranofaciens (Itoh, Toba, \& Adachi, 1992). Similar results were reported in other stud- ies (Batra, Singh, Banerjee, \& Patnaik, 2002). These results were partly in agreement with our results.

\subsection{Determination of lactose hydrolysis}

Lactose hydrolysis is considered as a major industrial process which appears to be highly underutilized today. In addition to one of the main uses of lactose hydrolysis for elimination of the lactose malabsorption problem, other prospective applications can be listed as prevention of lactose crystallisation in concentrated dairy products, production of oligosaccharides and exopolysaccharides, and enhancement of starter culture production (Ganzle, Haase, \& Jelen, 2008). With this persepective, lactose hydrolysing potential of enzymes from pure and mixed cultures were tested in $5 \%$ lactose.

The lactose $(5 \% \mathrm{w} / \mathrm{v})$ hydrolysis profiles of $\beta$-galactosidase of pure and mixed cultures are presented in Fig. 3. Nearly 60\% of lactose was hydrolysed at the end of $4 \mathrm{~h}$ for all the sources. However, at the end of $8 \mathrm{~h}, 80 \%$ of hydrolysis was achieved by the enzyme of the mixed culture (Lb 77 and St 95/2). This was 6.25\% and 10\% more than the hydrolysis of the enzymes of the pure strains of St 95/2 and Lb 77, respectively. These percentages were observed as a pattern for each sampling interval. Although the percentages seem to be low, if considered on a large scale where small increases can create big differences, this is a positive outcome which should not be ignored. Besides, with this particular study, where lactose, mainly found in milk and milk products, was considered as a substrate, the superiority of $\beta$-galactosidase of the mixed culture was demonstrated. With our previous study we have proved that associative growth provided $8.7 \%$ and $44.4 \%$ more lactic acid $(6.4 \%)$ and more $\beta$-galactosidase (39.3\%) than did pure St $95 / 2$ and Lb 77 strains (Tari et al., 2009). In fact, this has been proven by a two sample $t$-test by Minitab 14 statistical software (Minitab Inc., PA, USA), which confirmed the significant improvements (data not shown). Therefore, the expectation is that, in real applications, the $\beta$-galactosidase of the mixed culture will provide a better outcome. In one study, authors used mixed cultures of L. acidophilus (NCIM 2903) and Lactobacillus plantarum (NCIM 2083) in control and herbal yoghurts and determined that herbal yoghurts had maximum $\beta$-galactosidase activity (Chowdhury, Chakraborty, \& Raychaudhuri, 2008). Since there is no report, to best of our knowledge, on the application of the $\beta$-galactosidase of the mixed culture of $L$. bulgaricus and $S$. thermophilus, a direct comparison cannot be made. However, considering pure strains, up to 60\% hydrolysis in $4 \mathrm{~h}$ was obtained in a study reported by Kreft, Roth, and Jelen (2001) using Lactobacillus delbrueckii ssp. bulgaricus ATCC 11842. Additional research would be needed to investigate the applications of these enzymes to dairy products from a technological point of view.

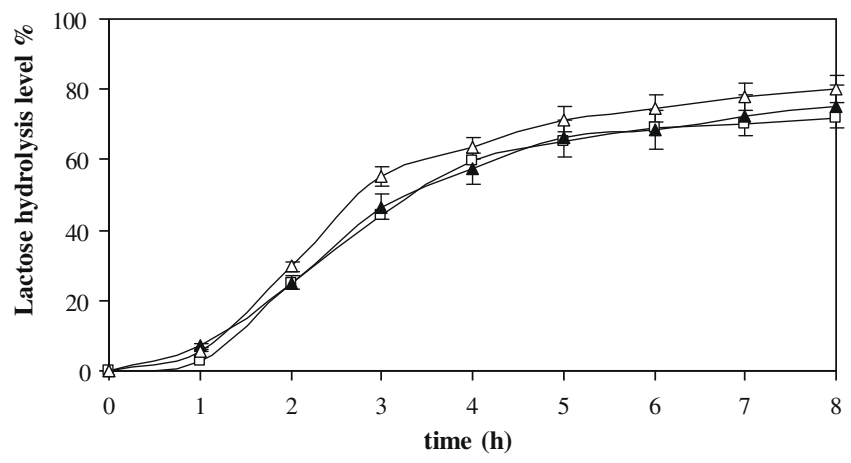

Fig. 3. Lactose hydrolysis profiles of crude $\beta$-galactosidase extracts from Lb 77 ( $\square$ ), St $95 / 2(\Delta)$ and Lb 77 and St 95/2 ( $\Delta)$. The data used on the graphs are the average values of two experiments. 


\section{Conclusion}

This study clearly indicated that there are some differences in the biochemical and thermal properties of the enzymes obtained from pure and mixed cultures. This study, not only introduced enzymes from new isolated strains, but also provided a new concept of using the enzyme of mixed cultures. This would eliminate the operating costs where whole strains in associative relationships are used as enzyme sources in dairy manufacture. Furthermore, $\beta$-galactosidases of bacterial sources (especially of GRAS status) which are more thermostable than are commercial yeast enzymes are becoming more attractive in view of the current prebiotic concept. Considering that there are no studies on the thermodynamic characterisation of $\beta$-galactosidase of LAB cultures in the literature, this study provides information valuable for the food and enzyme industries.

\section{Acknowledgements}

Financial support of the Turkish Scientific and Technical Research Council (TUBITAK-TOVAG 1040270) and State Plan Organization (DPT-2005 K 120570) are gratefully acknowledged.

\section{References}

Batra, N., Singh, J., Banerjee, U. C., \& Patnaik, P. R. (2002). Production and characterization of a thermostable $\beta$-galactosidase from Bacillus coagulans RCS3. Biotechnology and Applied Biochemistry, 36, 1-6.

Berger, J. L., Lee, B. H., \& Lacroix, C. (1997). Purification, properties and characterization of a high-molecular-mass $\beta$-galactosidase isoenzyme from Thermus aquaticus YT-1. Biotechnology and Applied Biochemistry, 25, 29-41.

Bhatti, H. N., Asgher, M., Abbas, A., Nawaz, R., \& Sheikh, M. A. (2006). Studies on kinetics and thermostability of a novel acid invertase from Fusarium solani. Journal of Agricultural and Food Chemistry, 54, 4617-4623.

Bhowmik, T., Johnson, M. C., \& Ray, B. (1987). Factors influencing synthesis and activity of $\beta$-galactosidase in Lactobacillus acidophilus. Journal Industrial Microbiology, 2, 1-7.

Büyükkileci, A. O., \& Harsa, S. (2004). Batch production of L(+) lactic acid from whey by Lactobacillus caseii (NRRL-B 441). Journal of Chemical Technology and Biotechnology, 79, 1036-1040.

Chowdhury, B. R., Chakraborty, R., \& Raychaudhuri, U. (2008). Study on $\beta$ galactosidase enzyme activity of herbal yoghurt. International Journal of Food Science and Nutrition, 59(2), 116-122.

Cortes, G., Trujillo-Roldan, M. A., Ramirez, O. T., \& Galindo, E. (2005). Production of $\beta$-galactosidase by Kluyveromyces marxianus under oscillating dissolved oxygen tension. Process Biochemistry, 40, 773-778.

Erkuş, O., Celik, E. S., Yavuzdurmaz, H., Okuklu, B., \& Harsa, S. (2006). Isolation and molecular characterization of artisanal yoghurt starter bacteria. In The twentieth international ICFMH symposium on food safety and food biotechnology: Diversity and global impact. Bologna, Italy [Preprints].

Ganzle, M. G., Haase, G., \& Jelen, P. (2008). Lactose: Crystallization, hydrolysis and value-added derivatives. International Dairy Journal, 18, 685-694.
Greenberg, N. A., \& Mahoney, R. R. (1982). Production and characterization of $\beta$ galactosidase from Streptococcus thermophilus. Journal of Food Science, 47, 1824-1828.

Ishikawa, E., Sakai, T., Ikemura, H., Matsumoto, K., \& Abe, H. (2005). Identification, cloning and characterization of Sporobolomyces singularis $\beta$-galactosidase-like enzymes involved in galacto-oligosaccharides production. Journal of Bioscience and Bioengineering, 99(4), 331-339.

Itoh, K., Toba, T., \& Adachi, S. (1992). Properties of $\beta$-galactosidase of Lactobacillus kefiranofaciens $\mathrm{K}-1$ isolated from kefir grains. Letters in Applied Microbiology, 15, 232-234.

Jurado, E., Camacho, F., Luzon, G., \& Vicaria, J. M. (2002). A new kinetic model proposed for enzymatic hydrolysis of lactose by a $\beta$-galactosidase from Kluyveromyces fragilis. Enzyme and Microbial Technology, 131, 300-309.

Kreft, M. E., \& Jelen, P. (2000). Stability and activity of $\beta$-galactosidase in sonicated cultures of Lactobacillus delbrueckii ssp bulgaricus 11842 affected by temperature and ionic environments. Journal of Food Science, 65, 1364-1368.

Kreft, M. E., Roth, L., \& Jelen, P. (2001). Lactose hydrolyzing ability of sonicated cultures of Lactobacillus delburickii ssp. bulgaricus 11842. Lait, 81, 355-364.

Laemmli, U. K. (1970). Cleavage of structure proteins during the assembly of the head of bacteriophage T4. Nature, 227, 680-685.

Mahoney, R. R., \& Wilder, T. (1989). Stabilization of lactase (Escherichia coli) by milk components and related compounds. Journal of Food Science, 54(4), 899-901.

Montanari, G., Zambonelli, C., Grazia, L., Benevelli, M., \& Chiavari, C. (2000). Release of $\beta$-galactosidase from Lactobacilli. Food Technology and Biotechnology, 38(2), 129-133.

Nagy, Z., Kiss, T., Szentirmai, A., \& Biro, S. (2001). $\beta$-Galactosidase of Penicillium chrysogenum: Production purification and characterization of the enzyme. Protein Expression and Purification, 21, 24-29.

Naidu, G. S. N., \& Panda, T. (2003). Studies on pH and thermal inactivation of pectolytic enzymes from Aspergillus niger. Biochemical Engineering Journal, 16, 57-67.

National Academy of Sciences (1996). Food chemicals codex (4th ed.). Washington, DC: National Academy Press. pp. 802-803.

Ortega, N., de Diego, S., Perez-Mateos, M., \& Busto, M. D. (2004). Kinetic properties and thermal behavior of polygalacturonase used in fruit juice clarification. Food Chemistry, 88, 209-217.

Rao, M. V., \& Dutta, S. M. (1981). Purification and properties of betagalactosidase from Streptococcus thermophilus. Journal of Food Science, 46, 1419-1423.

Rodriguez-Lopez, J. N., Fenoll, L. G., Tudela, J., Devece, C., Sanchez-Hernandez, D., de los Reyes, E., et al. (1999). Thermal inactivation of mushroom polyphenoloxidase employing $2450 \mathrm{MHz}$ microwave radiation. Journal of Agricultural and Food Chemistry, 47, 3028-3035.

Roe, S. (2001). Protein purification techniques: A practical approach. Bradford dye binding assay. Oxford University Press. p. 31.

Shah, N. P., \& Jelen, P. J. (1991). Lactase activity and properties of sonicated dairy cultures. Milchwissenschaft, 46(9), 570-573.

Shuler, M. L., \& Kargi, F. (2002). Bioprocess engineering basic concepts (2nd ed.) Upper Saddle River: Prentice Hall. p. 57.

Somkuti, G. A., \& Steinberg, D. H. (1979). $\beta$-D-galactoside galactohydrolase of Streptococcus thermophilus: Induction, purification and properties. Journal of Applied Biochemistry, 1, 357-368.

Tari, C., Ustok, F. I., \& Harsa, S. (2009). Optimization of the associative growth of novel yoghurt cultures in the production of biomass, $\beta$-galactosidase and lactic acid using response surface methodology. International Dairy Journal, 19 236-243.

Vasiljevic, T., \& Jelen, P. (2001). Production of $\beta$-galactosidase for lactose hydrolysis in milk and dairy products using thermophilic lactic acid bacteria. Innovative Food Science and Emerging Technology, 2, 75-85.

Voget, C. E., Flores, M. V., Faloci, M. M., \& Ertola, R. J. J. (1994). Effects of the ionic environment on the stability of Kluyveromyces lactis $\beta$-galactosidase. Lebensmittel Wissenschaft und Technologie, 27(4), 324-330. 